\title{
PRIMARY CARE SENSITIVE ADMISSIONS IN PREGNANT WOMEN: ASSOCIATED FACTORS BASED ON THE PRENATAL CARE PROCESS
}

\author{
Érica de Brito Pitilin ${ }^{1}$, Sandra Marisa Pelloso ${ }^{2}$
}

\footnotetext{
${ }^{1}$ MSc. in Nursing. Professor, Undergraduate Course in Nursing. Universidade Federal da Fronteira Sul. Chapecó, Santa Catarina, Brazil. E-mail: erica.pitilin@uffs.edu.br

2 Ph.D in Nursing. Professor, Undergraduate and Postgraduate Courses in Nursing, Health Sciences Center, Universidade Estadual de Maringá. Maringá, Paraná, Brazil. E-mail: smpelloso@uem.br
}

\begin{abstract}
Objective: to analyze admissions for primary care sensitive conditions among pregnant women, and the associated factors, based on the process of prenatal care, in a city of the center-west of the Brazilian State of Paraná (Brazil).

Method: this is an inquiry into hospital morbidity undertaken with a sample of 86 pregnant women admitted to hospitals serving the Unified Health System.

Results: the percentage of admissions was $70.97 \%(n=59)$, with emphasis placed on admissions specifically during the period of pregnancy $(51.17 \%)$, among which, admissions due to infections in the genitourinary tract were the most frequent. The following were associated with the risk of admission due to a sensitive condition: incomplete records in the woman's 'pregnancy card' (cartão da gestante), delayed initiation of prenatal care (after the second trimester), insufficient number of consultations and insufficient care during the consultation. Conclusion: the results suggest that a minimumlevel of care for these pregnant women would reduce the risk of unnecessary admission, evidencing that the quality of care provided during the prenatal period in this region is inadequate.

DESCRIPTORS: Pregnant women. Hospitalization. Prenatal care. Primary health care. Health evaluation.

\section{INTERNAÇÕES SENSÍVEIS À ATENÇÃO PRIMÁRIA EM GESTANTES: FATORES ASSOCIADOS A PARTIR DO PROCESSO DA ATENÇÃO PRÉ-NATAL}

\section{RESUMO}

Objetivo: analisar as internações por condições sensíveis à atenção primária em gestantes e os fatores associados a partir do processo da atenção pré-natal em um município pólo do Centro-oeste paranaense (Brasil).

Método: trata-se de um inquérito de morbidade hospitalar realizado com amostra de 86 gestantes internadas em hospitais conveniados ao Sistema Único de Saúde.

Resultados: o percentual de internações foi de 70,97\% (n=59), com destaque para as internações específicas do período gravídico (51,17\%), das quais as internações por infecções no trato geniturinário foram as mais frequentes. Associaram-se ao risco de internar por condição sensível: registro incompleto do cartão da gestante, início tardio da assistência pré-natal (a partir do $2^{\circ}$ trimestre), número insuficiente de consultas e conduta clínica inadequada durante a consulta.

Conclusão: os resultados sugerem que um acompanhamento mínimo dessas gestantes diminuiria o risco de internações desnecessárias pressupondo que a qualidade da assistência prestada durante o pré-natal na região apresenta-se insuficiente.

DESCRITORES: Gestantes. Hospitalização. Cuidado pré-natal. Atenção primária à saúde. Avaliação em saúde. 


\title{
INTERNACIONES SENSIBLES A LA ATENCIÓN PRIMARIA EN GESTANTES: FACTORES ASOCIADOS A PARTIR DEL PROCESO DE ATENCIÓN PRE-NATAL
}

\begin{abstract}
RESUMEN
Objetivo: analizar las internaciones por condiciones sensibles a la atención primaria en gestantes y los factores asociados a partir del proceso de atención pre-natal en una municipalidad polo del Centro-oeste paranaense (Brasil).

Método: encuesta de morbilidad hospitalaria realizado con una muestra de 86 gestantes internadas en hospitales con convenio al Sistema Único de Salud.

Resultados: el porcentual de internaciones fue de 70,97\% (n=59), con destaque para las internaciones especificas del periodo gravídico $(51,17 \%)$ de las cuales las internaciones por infecciones en el tracto genitourinario fueron las más frecuentes. Se asociaron al riesgo de internar por condición sensible: registro incompleto de la tarjeta de gestante, inicio tardío de la asistencia pre-natal (a partir del $2^{\circ}$ trimestre), número insuficiente de consultas y conducta clínica inadecuada durante la consulta.
\end{abstract}

Conclusión: los resultados sugieren que un acompañamiento minimo de estas gestantes disminuiría el riesgo de internaciones innecesarias presuponiendo que la calidad de la asistencia prestada durante la atención pre-natal en la región es insuficiente.

DESCRIPTORES: Mujeres embarazadas. Hospitalización. Atencion prenatal. Atención primaria de salud. Evaluación en salud.

\section{INTRODUCTION}

One of the indicators used most as an indirect instrument for assessing the resolutive capacity of the primary healthcare service (PHC) is the proportion of admissions due to primary care sensitive conditions (APCSC). These are understood as a set of health problems for which the effective action of primary care would reduce the risk of avoidable admissions. They are a health indicator, and contribute to understanding the determinants in the health-illness process. ${ }^{1}$

The indirect evaluation of primary care through the use of hospital indicators was initially studied in the United States, and is currently a topic which permeates discussions in various countries in the world scenario, in particular, in those which have adopted this level of care as a priority for the organization of their health systems, as it evaluates the impact of the reforms introduced in recent years. ${ }^{2-3}$

Brazil's current healthcare policy has prioritized investment in, and the reorganization of, $\mathrm{PHC}$, adopting the Family Health Strategy (Estratégia Saúde da Família - ESF) as its preferential model. Since this took place, studies have been undertaken in order to evaluate, even if indirectly, the quality of the healthcare offered in primary care, using data on potentially-avoidable admissions with the PHC services, demonstrating that the best coverage at this level of care is associated with the reduction of APCSC. ${ }^{4-5}$

In Brazil, APCSC were responsible for $34 \%$ of admissions paid for by the Unified Health System (SUS), costing the system R\$ 1.03 billion in costs resulting from hospital admissions; $51.9 \%$ of these admissions were of women. ${ }^{6}$ Some studies have evidenced proportions of admissions due to PCSC in women which are $28 \%$ higher than those for men. ${ }^{7-8}$ Moreover, upon ascertaining the groups of causes and the factors associated with sensitive admissions which are specific to women, being pregnant presented a higher risk of admission due to PCSC than did the other groups. ${ }^{9}$ However, few works have been published in relation to the topic in the Brazilian and international scientific production at the time of writing evidencing which groups of causes of admissions are related to the pregnant women, indirectly evaluating the quality of the prenatal care.

According to the Ministry of Health ( $\mathrm{MH})$, the assessment of the health policy for pregnant women at the primary level in Brazilian municipalities showed the existence of technical and administrative difficulties in the majority of these, resulting in questions on the quality of care provided to the pregnant woman, and on the impact of the health results indicators in this group. ${ }^{10}$ In view of this, the need is evidenced to undertake analysis in greater depth regarding the evaluation of these services through the determinants of the profile of pregnant women's hospital admissions which are sensitive to primary care, which could provide support for increasing the PHC's capacity to resolve health issues through identifying factors which could be improved in this area and to contributing to the professionals - principally nurses - inserting new conducts and routines in the attendance of women during pregnancy.

Even with the increase of $350 \%$ in coverage of prenatal care through the ESF in Brazil, the evaluations referent to the quality of the process of care for the pregnant woman continue to be concerning, as only a small percentage of women receives adequate care during the pregnancy, contributing to the occurrence of avoidable harm and unnecessary 
admissions. ${ }^{11-13}$ As a result, this study is based on the premise that a minimum treatment of these pregnant women would reduce the risk of admission. In the light of this, the authors analyzed the proportion of admissions due to conditions sensitive to primary care in pregnant women and the factors which determine or influence the occurrence of these admissions, based on the process of prenatal care in a city of the center-west of the Brazilian State of Paraná.

\section{METHOD}

This is a transversal prospective study based in an inquiry into hospital morbidity undertaken in March - June 2014, in the city of Guarapuava, Paraná, the hub of the 5th Health Region, with a population estimated at 167,328 inhabitants. ${ }^{14}$ The city has two general hospitals of medium and high complexity - the first is predominantly private (hospital 1) while the second is characterized as a non-profit making charity (hospital 2). The maternity units of both hospitals are centers of excellence for attending high-risk pregnancies. The city's ESF teams cover $52.9 \%(n=98)$ of the population.

The total number of admissions in pregnant women registered in the two institutions in the maternity departments in the year prior to data collection was 363 admissions, excluding the births. In order to determine the sample calculation, the authors considered a global proportion of APCSC estimated at $50 \%$ for each institution, with acceptable error of $5 \%$, confidence interval of $95 \%$ and an addition of $20 \%$ for margin of error in order to confer greater statistical stability. The sample resulted in 22 pregnant women for hospital 1, and 64 for hospital 2 , resulting in a final sample of 86 pregnant women.

The following were eligible for interview: the pregnant women admitted through the SUS in the two institutions, who had undertaken/were undertaking the prenatal monitoring in the public health network. The minimum age was 14 years old, as admissions of women below that age take place in the pediatric department. There was no upper age limit for inclusion in the study. Admissions transferred to other units were excluded.

Firstly, the pregnant women were interviewed during their hospital admission. Each hospital was visited between Mondays and Fridays. On the day of visiting, all the pregnant women admitted were interviewed and, with each new visit, the women who had already participated were excluded, with only the new cases remaining. Later, the investigation regarding the health condition which led to admission was undertaken through a search in the patient's electronic medical records. Only the main diagnosis recorded in the Authorization for Hospital Admission (AIH, in Portuguese) was considered.

A semistructured questionnaire was used, with questions addressing sociodemographic and economic information related to the use of the health services, perception regarding the quality of care received as an outpatient, and evaluation of the prenatal care process. Besides this, the pregnant woman's pregnancy card (cartão da gestante) was also assessed. The following were defined as independent variables in relation to the outcome of the study: sociodemographic characteristics (age, marital status, educational level, housing conditions and income) as well as variables related to the use of the health services, such as previous submission (in the last 12 months), regular health checkups (deduced from the regular and periodical attendance to the health services in the last 12 months), the place to which patients were referred for regular health checkups, the professional who indicated admission, and perception regarding the quality of healthcare received as an outpatient.

Furthermore, the variables investigated which were recorded on the woman's 'pregnancy card' were: a) number of consultations in the prenatal period (obtained by counting the records of the dates of the consultations and considering a minimum number of 6 as appropriate); b) gestational age (GA) in weeks; c) initiation of prenatal care in the first trimester (up to the $13^{\text {th }}$ week); d) minimum of six consultations undertaken, adjusted according to GA (with one in the first trimester, two in the second trimester (14 $4^{\text {th }}$ to $27^{\text {th }}$ week) and three in the third trimester (from the 28th week)); and e) procedures undertaken during the clinical consultation (with the following considered appropriate: checking of blood pressure (BP), weight, fundal height measurement (FHM) and the recording of fetal heart beat (FHB) with at least one record detected in the first three consultations); f) all vaccinations up-to-date (considering the presence of records of vaccines against tetanus, hepatitis B and influenza); g) collection taken for the Papanicolaou test during pregnan$\mathrm{cy} ; \mathrm{h}$ ) laboratory tests (considered complete if tests undertaken for bloodtyping, toxoplasmosis, HIV/ AIDS, syphilis, hepatitis B, complete blood count, urinalysis, urine culture, and fasting glycemia, and at at least two points during the pregnancy, and adjusted according to GA). The general record in the pregnancy card was considered complete when all the fields were filled out. All these aspects were 
checked dichotomously (for example, yes or no, adequate or inadequate, complete or incomplete).

In order to define the conditions for which admission is sensitive to primary care, the researchers used the list published by the $\mathrm{MH}$, used as an instrument for evaluating the primary care and for verifying the performance of the health systems. ${ }^{15}$ As a theoretical framework for analysis and interpretation of the data, the researchers adopted the National Policy for Comprehensive Assistance to Women's Health (Politica Nacional de Atenção Integral à Saúde da Mulher - PNAISM) ${ }^{10}$ in particular, relating to the line of care for the pregnant woman, and the Manual for Prenatal Care for Low Risk Pregnancies (Manual de Atenção ao Pré-natal de Baixo Risco). ${ }^{16}$

The SPSS software, version 20.0, was used for analyzing the data. In order to study the association between the independent variables and the occurrence or not of the outcome, bivariate analysis of the variables at each level of determination was undertaken at an early point using the Pearson Chi-squared tests. The Odds Ratio was used for the association between the variables.

Logistic regression was used for joint evaluation of the variables associated with hospitalizationsensitive conditions. The variables shown to be statistically significant in the bivariate analysis were selected for multivariate analysis, using the nonconditional backward stepwise method (likelihood ratio). A level of significance of $p<0.05$ was used for all the inferential statistical tests. The quality of the fit was evaluated using the Hosmer-Lemeshow test. The study was approved by the Research Ethics Committee of the State University of Maringá under protocol N. 304.032/06/05/2013 and Certificate of Presentation for Ethical Appreciation (CAAE) N.11729513.6.0000.0104.

\section{RESULTS}

The percentage of admissions sensitive to primary care in pregnant women was $70.97 \%(n=59)$ of the admissions which took place in the ambit of the SUS. Admissions specific to the period of pregnancy had the highest frequency $(51.17 \%)$. In relation to the sociodemographic characteristics of the population studied, $61.63 \%(n=53)$ were married, $51.16 \%(n=44)$ had a low educational level, and $75.57 \%(n=62)$ had an income of up to two minimum salaries. The mean age was 26.01 years old ( $\delta 8.07)$. Table 1 shows the characteristics of the pregnant women admitted according to the variables related to use of the health services. Although the women had undertaken the prenatal care in the ESF, $63.95 \%(n=55)$ were admitted by physicians of the units to which they were referred, outpatient centers or from the hospitals themselves to which the pregnant women were admitted.

Table 1 - Characteristics of the pregnant women admitted to the maternity unit, according to variables related to use of the health services in the Family Health Strategy. Guarapuava, PR, Brazil, 2014

\begin{tabular}{lcc}
\hline Variables & \multicolumn{2}{c}{$\mathbf{8 6}$ admissions } \\
\cline { 2 - 3 } Undertakes regular health checkups & $\mathbf{n}$ & $\mathbf{\%}$ \\
$\quad$ Yes & 57 & 66.28 \\
No & 29 & 33.72 \\
Resides in the area of the Family Health Strategy & & \\
$\quad$ Yes & 79 & 91.86 \\
No & 07 & 8.14 \\
Has a link with the Family Health Strategy & & \\
Yes & 45 & 52.32 \\
No & 41 & 47.68 \\
Indication for admission & & \\
Physicians of the Family Health Strategy & 31 & 36.05 \\
Other physicians & 55 & 63.95 \\
Duration of hospital stay (days) & & \\
$1-4$ & 33 & 38.37 \\
$5-9$ & & 53.49 \\
$10-14$ & 46 & 07
\end{tabular}




\begin{tabular}{|c|c|c|}
\hline \multirow{2}{*}{ Variables } & \multicolumn{2}{|c|}{86 admissions } \\
\hline & n & $\%$ \\
\hline \multicolumn{3}{|c|}{ Previous admission (last 12 months) } \\
\hline Yes & 16 & 18.60 \\
\hline No & 70 & 81.40 \\
\hline \multicolumn{3}{|c|}{ Admission for Primary Care Sensitive Conditions } \\
\hline Yes & 59 & 70.97 \\
\hline No & 27 & 31.36 \\
\hline \multicolumn{3}{|c|}{ Conditions Sensitive to Primary Care specific to the period of pregnancy } \\
\hline Yes & 44 & 51.17 \\
\hline No & 42 & 48.83 \\
\hline \multicolumn{3}{|c|}{ Perception regarding the Family Health Strategy } \\
\hline Excellent & 06 & 6.98 \\
\hline Good & 09 & 45.34 \\
\hline Acceptable & 35 & 40.70 \\
\hline Bad & 03 & 3.49 \\
\hline Very bad & 03 & 3.49 \\
\hline
\end{tabular}

The causes for the admissions among pregnant women are distributed according to gestational trimester, and were classified as APCSC and nonsensitive condition (Table 2). The main causes for APCSC were genitourinary tract infections (GTI)) in the $2^{\text {nd }}$ and $3^{\text {rd }}$ trimester. On the other hand, the prevalent non-sensitive admissions were for threat of miscarriage in the $1^{\text {st }}$ trimester and unspecified maternal hypertension in the $2^{\text {nd }}$ and $3^{\text {rd }}$ trimester.

Table 2 - Principal causes of admissions in a sample of pregnant women, inpatients, distributed among sensitive and non-sensitive conditions, according to gestational trimester. Guarapuava, PR, Brazil, 2014

\begin{tabular}{|c|c|c|c|c|c|c|c|c|}
\hline \multirow{3}{*}{$\begin{array}{l}\text { Causes } \\
\text { Sensitive to primary care }\end{array}$} & \multicolumn{6}{|c|}{ Trimester } & \multirow{2}{*}{\multicolumn{2}{|c|}{ Total }} \\
\hline & \multicolumn{2}{|c|}{ First } & \multicolumn{2}{|c|}{ Second } & \multicolumn{2}{|c|}{ Third } & & \\
\hline & $\mathbf{n}$ & $\%$ & $\mathbf{n}$ & $\%$ & $\mathbf{n}$ & $\%$ & $\mathbf{n}$ & $\%$ \\
\hline Genitourinary tract infections pregnancy & - & - & 37 & $43.0^{*}$ & 12 & 13.9 & 49 & 56.9 \\
\hline Pneumonia & 1 & 1.1 & 3 & 5.8 & - & - & 4 & 7.0 \\
\hline Iron-deficiency anemia & - & - & 2 & 2.3 & 3 & 3.4 & 5 & 5.8 \\
\hline Non-specific complications of diabetes & - & - & 1 & 1.1 & - & - & 1 & 1.1 \\
\hline Subtotal & 1 & 1.1 & 43 & 52.3 & 15 & 17.4 & 59 & 70.9 \\
\hline \multicolumn{9}{|l|}{ Non-sensitive to primary care } \\
\hline Unspecified maternal hypertension & - & - & 5 & 5.8 & 5 & 5.8 & 10 & 11.6 \\
\hline Premature labor & - & - & 2 & 2.3 & 3 & 3.4 & 5 & 5.8 \\
\hline Threat of miscarriage & 5 & 5.8 & - & - & - & - & 5 & 5.8 \\
\hline Severe preeclampsia & - & - & - & - & 3 & 3.4 & 3 & 3.4 \\
\hline Pyelonephritis & - & - & 1 & 1.1 & - & - & 1 & 1.1 \\
\hline Hyperemesis gravidarum & 2 & 2.3 & - & - & - & - & 2 & 2.3 \\
\hline Gestational edema & - & - & - & - & 1 & 1.1 & 1 & 1.1 \\
\hline Subtotal & 7 & 8.1 & 08 & 9.3 & 12 & 13.9 & 27 & 31.3 \\
\hline Total & 8 & 9.2 & 51 & 61.6 & 27 & 27.8 & 86 & 100 \\
\hline
\end{tabular}

* Significant difference within the age group of the sample for $\mathrm{p}<0.05$ (Fisher's exact test with Yates's correction). 
Table 3 shows the results of the bivariate analyses between the variables studied and the study's outcome, categorized as condition sensitive or not to primary care. In this first analysis, the variables shown to be associated were: incomplete records in the prenatal care card (cartão do pré-natal), delay in initiating prenatal care (beginning in the $2^{\text {nd }}$ trimester), insufficient care and negative perception of the ESF.

Table 3 - Bivariate analysis of the association between the characteristics studied and admission for primary care-sensitive conditions among pregnant women. Guarapuava, PR, Brazil, 2014

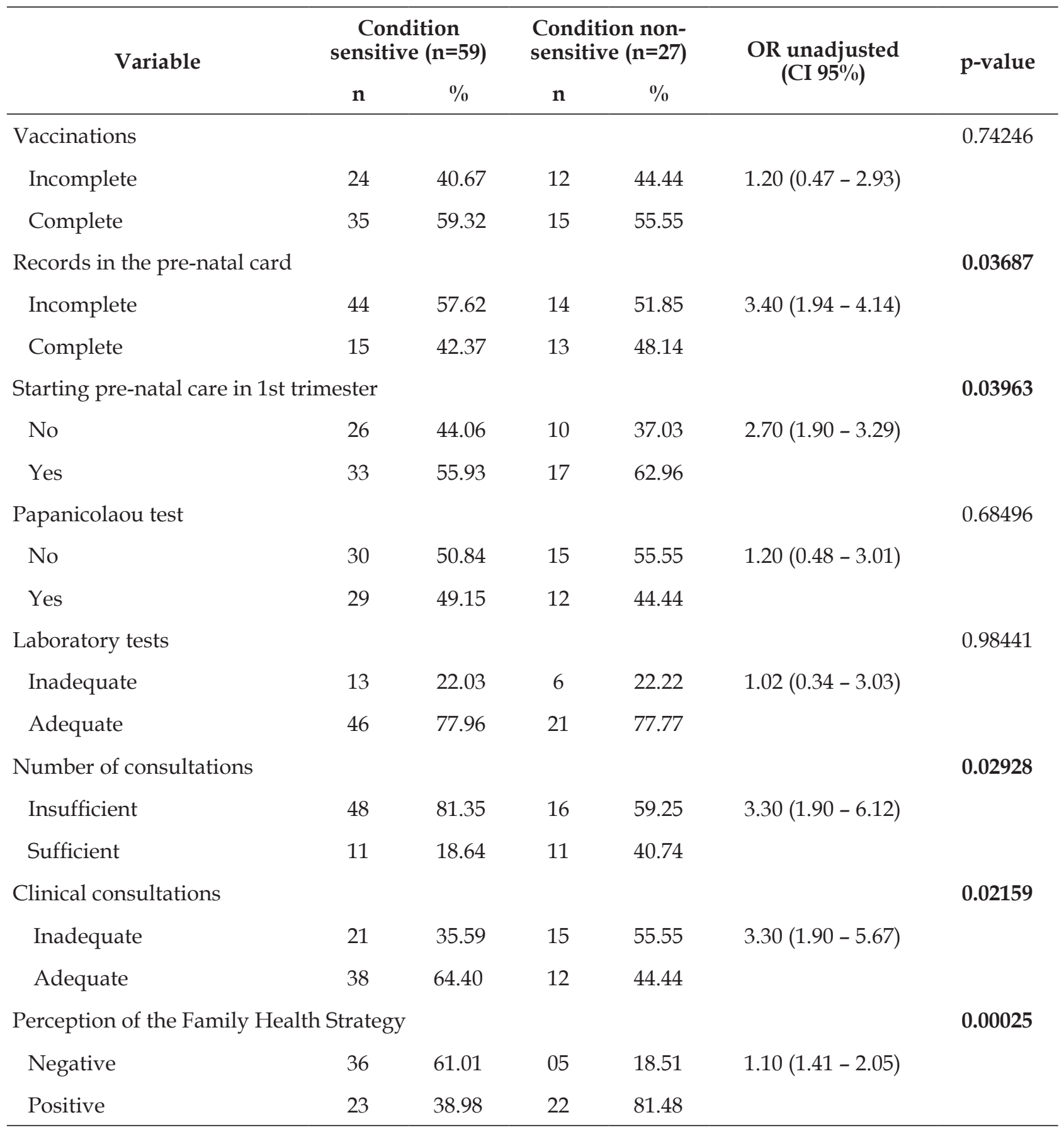

Table 4 shows the results of the multiple logistic regression analysis for control of the effects of the potential confounding variables. The variables shown to be statistically associated with the primary care sensitive conditions among pregnant women in the final adjusted model were: incomplete records in the pre-natal card, delay in initiating prenatal care, insufficient number of consultations, and insufficient care. 
Table 4 - Logistic regression of the factors associated with admission due to sensitive condition in pregnant women. Guarapuava, PR, Brazil, 2014

\begin{tabular}{lccc}
\hline Variable & $\begin{array}{c}\text { OR } \\
\text { Adjusted }\end{array}$ & CI 95\% & p-value \\
\hline Incomplete records in the pre-natal card & 2.31 & $(1.39-3.52)$ & 0.00089 \\
Delay in initiating prenatal care & 2.07 & $(1.97-3.79)$ & 0.00092 \\
Insufficient number of consultations & 2.16 & $(1.48-3.22)$ & 0.00077 \\
Insufficient care & 2.40 & $(1.51-4.68)$ & 0.00089 \\
\hline
\end{tabular}

\section{DISCUSSION}

Admissions in the population of pregnant women due to PCSC showed a high percentage of admissions due to conditions which could have been avoided or reduced in the presence of timely and appropriate primary care. The principal cause of these admissions was GTI, with statistical significance for the $2^{\text {nd }}$ trimester, as evidenced in other studies. ${ }^{17-18}$ Although frequent during pregnancy, the prevalence of admission to hospital for treatment of GTI during pregnancy is an indicator of the inefficiency of the prenatal care. ${ }^{11}$ Early and qualified monitoring allows the identification of pregnant women at greater risk of developing GTI, making it possible to avoid these, as their prevalence is associated with worse maternal and perinatal prognoses. ${ }^{19}$

In the present study, insufficient presented a probability of being admitted for a sensitive condition which was 2.40 times higher than for the other variables. The quality of the process of the prenatal care, ascertained from the records of the procedures undertaken during the consultation, such as the clinical approach, physical examination, checking blood pressure, obstetric palpation, auscultation of FHB and assessment of nutritional status, among others, showed this not to be meeting the needs of the pregnant women, revealing a worse prognosis and the occurrence of unnecessary admissions, in the light of other studies undertaken in the States of Espírito Santo and Rio de Janeiro..$^{20-21}$

Furthermore, it may be added that the poor coverage of prenatal care, expressed by the low numbers in the records of the consultations, also revealed a shortcoming in the quality of the care provided, this resembling the results found in other studies., ${ }^{9,16}$ In medium-and low-income countries, inadequate monitoring during prenatal care is a significant risk factor for increases in perinatal mortality.$^{20}$ It is emphasized that failure to undertake the minimum number of consultations, adjusted according to GA, was associated with a risk 2.16 times greater of being admitted due to PCSC .

The reduction in the number of consultations may reflect delay in initiating prenatal monitoring, which suggests either an absence of compensatory mechanisms for ensuring these pregnant women's access to attendance, or a greater risk of being admitted for potentially avoidable conditions. Only $58.13 \%$ of the pregnant women interviewed began their prenatal care in the $1^{\text {st }}$ trimester, in consonance with other studies which also identified poor early capture in the care. ${ }^{13,22}$ The low proportion of pregnant women who began their prenatal care at an early stage in this study may be explained by the poor coverage of the ESF, showing that access to care at this level of care in the region continues to be poor.

The incomplete records in the pre-natal card were also associated with higher chances of admission due to PCSC specific to the period of pregnancy. The failure to fill out the fields present in the prenatal card is a concerning factor, as the filling-out of the prenatal card is one of the points of quality of the care provided to the pregnant woman, as this record has the role of allowing the flow of information between the health services and the monitoring of the progression of the pregnancy, birth and puerperium. ${ }^{16}$ In addition to this, the appropriate recording of data in the pregnancy card is valued by national guidelines as the source of information regarding the woman's prenatal care, throwing light on only one part of the needs of pregnant women in relation to the attendance. ${ }^{17}$ The fields left blank in the cards suggest the pregnant woman's absence from the service, or that her visits to the service were not appropriately recorded.

It is emphasized that in this study there was a lower proportion of records relating to the results of the laboratory tests, principally for the urinalysis, similar to the findings of studies undertaken in Rio de Janeiro and in Porto Alegre. ${ }^{23-24}$ It is possible that the results of the tests are not being 
recorded in the prenatal card or, even, that there is a delay in undertaking the same. The evaluation of the information on the pregnancy card in one systematic review, with a meta-analysis of 19 randomized clinical trials and approximately 17,000 participants, showed that dependent variables of the diagnostic tests were those which presented the highest percentages of missing data. ${ }^{20}$

In spite of the extending of coverage of prenatal care in Brazil, and the importance of the ESF teams in this extension, the persistence of problems associated with appropriate care offered to the pregnant woman is evident. Although, potentially, the ESF has advantages in the prenatal care, in comparison with the other models of health, one cannot conclude that it is only the pregnant woman's passing through the service's bureaucracy that promotes the quality of the care, considering that $79.97 \%$ of admissions were for sensitive conditions. Through construction of the model of health based in the ESF, there is a need for changes in the professional practices, which need to be undertaken in a form which is committed to the ESF's precepts and strategic proposals. ${ }^{25}$ The need is evidenced to reflect on the implications of the health professionals' training process, in particular that of the nurse, considering the premise that the care develops and/ or is acquired during the training and later passes into the professional space. ${ }^{26}$

These results demonstrate the challenge posed to prenatal care, and points to the need for continuous assessments of the health services so as to reduce the persistence of health issues considered avoidable. The program's capacity to resolve issues is related to its ability to fulfill its obligations, and it should be organized so as to meet the needs of the entire population of pregnant women, making use of appropriate means and resources available. ${ }^{27}$ Moreover, the care during the pregnancy needs to be permeated with humanization of care and by respect for the women as subjects throughout the entire process.

It is emphasized that the admissions analyzed were only those which took place in the ambit of the SUS, which signifies a partial vision of the context. However, this study may support reflections and discussions among professionals and management so as to improve the quality of the care offered to pregnant women. It is suggested that future studies should make use of the indicators of quality of primary care based in a conceptual framework which establishes which factors are influenced by this model of healthcare.

\section{CONCLUSION}

In this study, the majority of admissions of pregnant women were considered sensitive to PHC, which suggests shortcomings in the primary care, which should be timely and resolutive in the context of women's reproductive health, corroborating the study's initial hypothesis. If, on the one hand, the organization of the network of health services related to the ESF's poor population coverage may have contributed to high rates of admissions due to PCSC. On the other, the process of the prenatal care also contributed to the occurrence of the event, such as failures to fill out completely the pregnancy card, delay in initiating the care (after the beginning of the $2^{\text {nd }}$ trimester), an insufficient number of consultations, and insufficient care, supposing that a minimum treatment of these pregnant women would reduce the risk of avoidable admissions.

In addition to this, through the objectives of this study, it was possible to identify the other aspects in the process of the prenatal care, such as immunization, the Papanicolaou test and the requesting of laboratory tests, which also showed proportions below those stipulated by national directives and recommendations. It is worth highlighting that admissions due to maternal hypertension were the second most common cause, totaling $11.62 \%$ of the admissions. The diagnosis in question is not classified as a PCSC, but its control and monitoring are of extreme importance for fetal vitality and for reducing maternal mortality rates.

In spite of the findings evident in this study regarding the need to promote specific actions in the health care for pregnant women, it was not possible to obtain the outcome for pregnant women younger than 14 years old. It is stressed that the relevant information in the construction of the study was extracted from records made in the pregnancy card; in practice, these numbers may evidence another context. Furthermore, the diagnostic reliability in the records of Authorization for Hospital Admission (AIH) may configure another limitation of the study, given that the hospital information system has as its main objective to receive financial payment according to the procedure undertaken, and that there may therefore be a tendency to record more expensive procedures; and thus to hide a PCSC by recording it as not sensitive. Finally, the scientific knowledge acquired through this study could permeate the introduction of differentiated measures for practice. 


\section{REFERENCES}

1. Skinner HG, Coffey R, Jones J, Heslin KC, Moy E. The effects of multiple chronic conditions on hospitalization costs and utilization for ambulatory care sensitive conditions in the United States: a nationally representative cross-sectional study. BMC Health Services Research [Internet]. 2016 [cited 2016 May 05]; 16(77). Available from: http://www.ncbi. nlm.nih.gov/pubmed/26926525

2. Loenen TV, Faber MJ, Westert GP, VandenBerg MJ. The impact of primary care organization on avoidable hospital admissions for diabetes in 23 countries. Scand J Prim Health Care [Internet]. 2016 [cited 2016 May 05]; 34(1). Available from: http:/ / www.tandfonline. com/doi/pdf/10.3109/02813432.2015.1132883

3. Ansari Z, Rowe S, Ansari H, Sindall C. Small area analysis of ambulatory care sensitive conditions in Victoria, Australia. Popul Health Manag [Internet]. 2013 [cited 2015 Apr 12]; 16(3). Available from: http:/ / www.ncbi.nlm.nih.gov/pubmed/23405877

4. Batista SRR, Jardim PCBV, Sousa ALL, Salgado CM. Hospitalizações por condições cardiovasculares sensíveis à atenção primária em municípios goianos. Rev Saúde Pública [Internet]. 2012 [cited 2015 May 03]; 46(1). Available from: http:/ / dx.doi.org/10.1590/ S0034-89102012005000001

5. Mendonça CS, Harzheim E, Duncan BB, Nunes LN, Leyh $\mathrm{W}$. Trends in hospitalizations for primary care sensitive conditions following the implementation of Family Health Teams in Belo Horizonte, Brazil. Health Policy Plan [Internet]. 2012 [cited 2015 May 03]; 27(3). Available from: http:/ / www.ncbi.nlm.nih. gov/pubmed/21666271

6. Boing AF, Vicenzi RB, Magajewski, Boing AC, Moretti-Pires RO, Peres KG, et al. Redução das Internações por Condições Sensíveis à Atenção Primária no Brasil entre 1998-2009. Rev Saúde Pública [Internet]. 2012 [cited 2015 May 03]; 46(2). Available from: http://dx.doi.org/10.1590/S003489102012005000011

7. Cardoso CS, Pádua CM, Rodrigues-Junior AA, Guimarães DA, Carvalho SF, Valentin RF, et al. Contribuição das internações por condições sensíveis à atenção primária no perfil das admissões pelo sistema público de saúde. Rev Panam Salud Publica [Internet]. 2013 [cited 2015 Apr 13]; 34(4). Available from: http://www.scielosp.org/scielo.php?script=sci_ arttext\&pid=S1020-49892013001000003

8. Souza LL, Costa JSD. Internações por condições sensíveis à atenção primária nas coordenadorias de saúde no Rio Grande do Sul. Rev Saúde Pública [Internet]. 2011 [cited 2015 May 03]; 45(4). Available from: http://dx.doi.org/10.1590/S003489102011000400017

9. Pitilin EB, Gutubir D, Molena-Fernandes CA, Pelloso SM. Internações sensíveis à atenção primária específicas de mulheres. Cienc Saúde Coletiva [Internet]. 2015 [cited 2015 Sep 12]; 20(2). Available from: http:// www.scielosp.org/pdf/csc/v20n2/1413-8123csc-20-02-0441.pdf

10. Ministério da Saúde (BR), Departamento de Ações Programáticas e Estratégias, Política Nacional de Atenção Integral à Saúde da Mulher: princípios e diretrizes. Brasília (DF): MS; 2011.

11. Hackenhaar AA, Albernaz EP. Prevalência e fatores associados à internação hospitalar para tratamento da infecção do trato urinário durante a gestação. Rev Bras Ginecol Obstet [Internet]. 2013 [cited 2015 Apr 12]; 35(5). Available from: http://www.scielo.br/ pdf/rbgo/v35n5/02.pdf.

12. Niquini RP, Bittencourt AS, Lacerda EMA, Saunders C, Leal MC. Avaliação do processo da assistência nutricional no pré-natal em sete unidades de saúde da família no município do Rio de Janeiro. Cienc Saúde Colet [Internet]. 2012 [cited 2015 Jan 13]; 17(10). Available from: http://dx.doi.org/10.1590/S141381232012001000028

13. Andreucci CB, Cecatti, JG. Desempenho de indicadores de processo do Programa de Humanização do PréNatal e Nascimento no Brasil: uma revisão sistemática. Cad Saúde Pública [Internet]. 2011 [cited 2015 Apr 12]; 27(10). Available from: http://dx.doi.org/10.1590/ S0102-311X2011000600003

14. Instituto Paranaense de Desenvolvimento Econômicoe Social. IPARDES. 2013. Perfil dos municípios. Curitiba (PR): Instituto Paranaense de Desenvolvimento Econômico e Social.

15. Brasil. Portaria n. 221, de 17 de abril de 2008. Dispõe sobre a Lista Brasileira de Internações por Condições Sensíveis à Atenção Primaria e da outras providências. Diário Oficial da República Federativa do Brasil, 18 abr 2008. Seção I.

16. Ministério da Saúde (BR), Departamento de Ações Programáticas Estratégicas, Atenção ao Pré-Natal de Baixo Risco. Brasília: MS; 2012.

17. Amiri M, Lavasani Z, Norouzirad R, Najibpour R, Mohamadpour M, Nikpoor AR, et al. Prevalence of urinary tract infection among pregnant women and its complications in their newborns during the birth in the hospitals of Dezful City, Iran, 2012 - 2013. Iran Red Crescent Med J. [Internet]. 2015 [cited 2016 May 05]; 17(8). Available from: http:/ / www.ncbi.nlm.nih. gov / pubmed? $\mathrm{Db}=$ pubmed\&Cmd=Retrieve\&list_ uids $=26430526 \&$ dopt $=$ abstractplus

18. Haider G, Zehra N, Munir AA, Haider A. Risk factors of urinary tract infection in pregnancy. J Pak Med Assoc [Internet]. 2010; [cited 2015 May 13]; 60(3). Available from:http://www.ncbi.nlm.nih.gov/ pubmed/20225781

19. Labi AK, Yawson AE, Ganyaglo GY, Newman MJ. Prevalence and associated risk factors of asymptomatic bacteriuria in ante-natal clients in a large teaching hospital in Ghana. Ghana Med J [Internet]. 2015; [cited 2016 May 05]; 49(3). Available 
from: http:/ / www.ncbi.nlm.nih.gov/pmc/articles/ PMC4676592/pdf/GMJ4903-0154.pdf

20. Kikuchi K, Ansah EK, Okawa S, Enuameh Y, Yasuoka J, Nanishi K. et al. Effective linkages of continuum of care for improving neonatal, perinatal, and maternal mortality: a systematic review and meta analysis. Plos One [Internet]. 2015 [cited 2016 May 05]; 10(9). Available from: http://journals.plos.org/plosone/ article?id=10.1371 $/$ journal.pone.0139288

21. Coutinho T, Monteiro MFG, Sayd JD, Teixeira MTB, Coutinho CM, Coutinho LM. Monitoring the prenatal care process among users of the Unified Health Care System in a city of the Brazilian Southeast. Rev Bras Ginecol Obstet [Internet]. 2010; [cited 2015 Mar 23]; 32 (11). Available from: http://dx.doi.org/10.1590/ S0100-72032010001100008

22. Dowswell T, Carroli G, Duley L, Gates S, Gülmezoglu AM, Khan-Neelofur D, et al. Alternative versus standard packages of antenatal care for low-risk pregnancy. Cochrane Database Syst Rev [Internet]. 2010 [cited 2015 Sep 14]; 10 (14). Available from: http://apps.who.int/rhl/reviews/CD000934.pdf.

23. Domingues RMSM, Hartz ZMA, Dias MAB, Leal MC. Avaliação da adequação da assistência pré-natal na rede SUS do município do Rio de Janeiro, Brasil. Cad Saúde Pública [Internet]. 2012 [cited 2015 Apr 12];
28(3). Available from: http://dx.doi.org/10.1590/ S0102-311X2012000300003

24. Gomes RMT, César JA. Perfil epidemiológicos de gestantes e qualidade pré-natal em unidade básica de saúde em Porto Alegre, Rio Grande do Sul, Brasil. Rev Bras Med Fam Comunidade [Internet]. 2013 [cited 2015 Oct 15]; 8 (27).Available from: http://www. rbmfc.org.br/rbmfc/article/view/241.

25. Souza MG, Mandu ENT, Elias AN. Percepções de enfermeiros sobre seu trabalho na estratégia saúde da família. Texto Contexto Enferm [Internet]. 2013 [cited 2015 Aug 17]; 22(3). Available from: http://dx.doi. org/10.1590/S0104-07072013000300025

26. Alberti GF, Schimith MD, Budó MLD, Neves GL, Rosso LF. Atributo do primeiro contato na atenção básica e práticas de cuidado: contribuições para a formação acadêmica do enfermeiro. Texo Contexto Enferm [Internet]. 2016 [cited 2016 Aug 13]; 25(3). Available from: http://dx.doi.org/10.1590/010407072016004400014

27. Oliveira RLA, Fonseca CRB, Carvalhaes MABL, Parada CMGL. Avaliação da atenção pré-natal na perspectiva dos diferentes modelos na atenção primária. Rev Latino-Am Enfermagem [Internet]. 2013 [cited 2015 Aug 14]; 21(2). Available from: www.scielo.br/pdf/ rlae/v21n2/pt_0104-1169-rlae-21-02-0546.pdf. 